Anita Stefańska

Poland

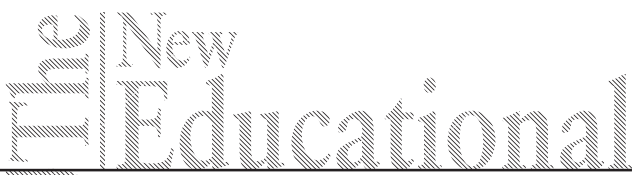

Review

\title{
Body... That Does Not Get Bored or About Supporting Non-verbal Communication in the Process of Drama Therapy of the Intellectually Disabled
}

DOI: 10.15804/tner.2015.41.3.19

\begin{abstract}
The aim of this study was to test the hypothesis of the impact of drama therapy on self-awareness of the role of the body among the intellectually disabled. In particular, it was intended to examine the effects of drama therapy involving improvisation on adolescents with moderate intellectual disability. The study is focused on assessing their levels of self- awareness of the role of the body in interpersonal relationships.

The instrument used for the purpose of this study was designed by the author. It consists of a "Body in action" test, which comprises 16 questions examining the level of self-evaluation of non-verbal behaviours in social interactions. The subjects were administered the test before and after a series of drama therapy workshops.

Results indicate the connection between participation in drama therapy workshops based on improvisation and an increased level of the participants' self-awareness of the role of the body in interpersonal relationships. At this stage of research, however, the conclusions cannot be extended to the whole age-group of the intellectually disabled.

This study constitutes a starting point for further exploration of this issue. It outlines a direction, since, based on the results obtained, it can be stated that non-verbal communication plays a significant role in the development of social competences.
\end{abstract}

Keywords: adolescents, body, intellectual disability, drama therapy, interpersonal communication 


\section{Introduction}

Body and mind are two different aspects of consciousness. M. Merleau-Ponty claims that body and mind are like heads and tails of the consciousness coin although their integration does not mean that they are the same. (M. Merleau-Ponty, 2002).

Body and mind clearly interpenetrate in the art of acting. By using their bodies, actors initiate, sustain and change relationships between characters, define such characters, their particular situations and tasks. In so doing, they use a certain set of bodily codes. The body position and movement in theatrical happening, actors' facial expressions, their touch and physical contact, the way they exchange looks, their physical appearance, gestures or distance in interpersonal space - all these contribute to creating characters in the theatre. In the process of evoking emotions or decoding behaviours caused by such emotions in the acting process, the search for proper, meaningful and well-grounded nonverbal signals plays an important role. A particular character's positions, their gestures, touch, facial expressions or such messages as laughter, tone and pitch of voice constitute the components on which interpersonal relationships are primarily based.

According to Aristotle, man is a social animal that by nature needs interactions (2010) and in them, the unity of body and mind. The importance of such integration is emphasized by R. Steiner (2003), C. Rogers (2002) and E. Fromm (2005). Man is obliged to "integrate himself with his own body (J. Kopania, 2002, p. 226). Merleau-Ponty compares the body to a work of art, considering it as "an ensemble of lived meaning". As he writes, "I am conscious of my body via the world, [...] and in that sense I am conscious of the world through the medium of my body $(2002 ; 94)$.

\section{The role of the body in shaping personal identity and perceiving the world}

Sensorimotor sensations may activate a vast array of other sensations originating in the body, at the same time engaging feelings and visual imagery. The body and its reactions enable people to perceive the state of others, react to it and participate in what they experience.

D.N. Sterns expresses the view that nonverbal knowledge is a system that develops and operates throughout human life in parallel to verbal knowledge (D.N. Stern, 2004). Thanks to this knowledge, which is closely connected with 
nonverbal communication, in a way people perceive others in terms of internal states.

This holistic perception of corporality constitutes the basis of drama therapy, in which onstage performance illustrates how various acting techniques can be used to support the development of individuals with developmental, psychic and social problems. Drama therapy also draws upon Konstanty Stanisławski's view that an actor shall act in a motivated, purposeful and creative way and if an actor performs on their own behalf, their action becomes real, not imitated (as cited in: Duda, p. 227). The underlying idea of drama therapy is an actor who acts on their own behalf.

The distinguishing feature of this form of therapy is that "by using and developing the ability to perform characters and enter dramatic reality, it relies in its therapeutic effect on the whole experience accumulated in the process of building a role and in an act of creating drama (D. Podgórska - Jachnik, 2011, p. 105). Irena Lewkowicz writes: "It is not onstage acting, but man - his posture, <nontransparent $>$ silhouette, his own pattern of gestures - ... that expresses more than the onstage meaning ( I. Jajte-Lewkowicz, 2006, p. 283). In the process of drama therapy, the body is a means of communication within the framework of fictitious stimulation - in compliance with the principle of conventionality - not in reality as such. ${ }^{1}$

According to Sue Jennings, it is therefore essential that the participant shall be able to distinguish the reality of drama play from everyday reality (1995, pp. 132-141). Moreover, in establishing acting tasks, as understood in the context of the traditional physical theatre, it is necessary to account for the limited ability of the intellectually disabled to imagine psychic dilemmas of others.

Playing, or in other words work through the role, creates an opportunity for the participant to communicate in ways other than verbal, thus enabling the exploration of their resources at the level of their physicality, movement and sound, which creates a framework for interpersonal relations (M. Nowakowska, 2006, p.9). Associations originating in the kinesthetic and symbolic areas extend the perceptive resources of an individual beyond verbal reasoning. In addition, as DavidJohnson points out, movement seems to involve an increase in the awareness of internal states (1985).

1 Such perception of the body is applied in practice for the development through creative drama activities, among others, by: Justyna Sobczyk Theatre 21, Warsaw, Poland, Natali (Krug Theatre, Moscow, Russia), professor Jana Pliatova (AMU, Prague, Czech Republic), Erdmute Sobaszek (Węgajty Theatre, Poland and Germany), Maria Pietruszka-Budzyńska (Lublin Drama Therapy), Danse Brute Theatre (Vienna), Slutspil Theatre (Aarhus, Denmark), Bohnice Theatre (Czech Republic), Dancing with the Difference Theatre ( Madera, Portugal). 
Drama activities in the therapy of the intellectually disabled are focused on the expression of the body in order to facilitate the expression of emotions that would otherwise be difficult to express. It is so, because usually it would be difficult for the disabled to find proper equivalent words. As Hollis Huston puts it, "The expression of the body constitutes the projection not only of the corporality as such, but of man perceived as a whole" (1995, p.52).

The actor comprehensively analyses the character played, considering acting as participation in the other person's experience, and uses his physicality to create a figure of this person, thus becoming a projection of this expression. In the process of drama therapy, for the actor with a weaker perception the transformation of "real" action into "dramatic" one may add new semantic functions to reality (I. Lewkowicz, 2006:282). Non-verbal communication, by its visuality, becomes more specific and thus more obvious for the participants. According to Rudolf Laban, actors find it most difficult to understand that "There are many more gestures than words to describe feelings (R. Laban, 1975: 234). Katarzyna Krasoń describes the act of bodily creation: "When we start to combine gestures, the scenes make the participants get closer, also in terms of ideation. It can be said that negotiation that takes place in the sphere of movement gives more opportunities for agreement than any attempts to convince one another verbally" (2013, p.278). In drama therapy a similar stage can be clearly seen when the human body is an instrument through which the actor's presence is manifested in a unique and individual way. Actors' movements, consistent with their psychomotor abilities, are not the ultimate aim. Onstage movement needs to be commensurate with the actor's abilities, but also purposeful and justified. This is achieved by discussing cause-and-effect relationships in human behaviors or by finding a rationale for the necessity of harmony between movement and mime. The questions arise: What did you feel at the physical level? What was happening to your body at that time? Why? For whom or against whom are you acting? Partners collaborate with one another in order to adjust the task involving movement and in so doing they take into account each other's limitations and abilities.

\section{Theoretical assumptions}

A. Awgiejew - Z. Nęcki pragmatic - contextual typology of communication acts assumes that the essence of communication is the exchange of verbal, vocal and nonverbal symbols and the aim of this exchange is the enhancement of relationships between partners so that the interpersonal context and mutual relationships 
facilitate agreement rather than divide and hinder mutual contact (Nęcki, 2000: pp.100-132).

In therapeutic, educational and theatrical work, the way you stand, e.g., is an important form of communication. Quite often, not being aware of it or not paying attention to it, individuals do not control their posture, by which they are likely to distort communication with their environment or make the impression of behaving illogically. As a result, for many individuals with intellectual disability, communication with their environment abounds in emotional misunderstandings.

Amy Rakusin expresses the opinion that interaction between body and mind accounts for the fact that by changing the way the individual moves, we affect their whole functioning - for an intellectually disabled person this can mean the opportunity to discover the potential in themselves they so far have not been aware of (1990).

The main principle concerning body work in drama therapy is the assumption of the DTM that man is a unity of body and psyche. The concept of the Drama Therapy Model (DTM) is described in detail by A. Stefanska (2012) and the unity of body and psyche has been discussed, among others, by A. Lowen (2005), S. Keleman (1985), P.Knill, H. Barba, M.Fuks (1995), who emphasize the importance of psychomotor integration in development. The body naturally and clearly sends numerous emotional messages, which in turn affect psychomotor coordination. By drama activities, inseparably connected with physical activity, the transformation of the "real" action into "theatrical" one may give the reality new semantic functions .A nonverbal message, by its "visuality", becomes more tangible for the participants and thus clearer. Playing, as a phenomenon of the presence of body and mind, relies on such basic components as subject, symbolization, role, and fiction.

Playing, as a phenomenon of the presence of body and mind, draws on such components as subject, symbolism, role, and fiction. The proposed model of a drama therapy session (DTM) focused on role building draws upon the theory of mind and Gardner's theory of intelligence (1993).In understanding messages (both verbal and non-verbal) exchanged by the characters, it is of primary importance to understand their motivation and the meaning of the reaction of the body in particular circumstances.

The research is based on the developmental drama therapy approach (Malchiodi, 2014, p. 144), in which change is perceived not in the corrective aspect, but as the reinforcement, motivation and discovery of the individual's potential. Hence, drama therapy sessions focus on enhancing artistic, mental and psychological resources of participants. They do not aim to improve distorted functions. 
In drama therapy, experiences connected with artistic expression "enable people to analyse the so far unknown part of themselves, to communicate non-verbally (...)" (ibid. p.164). Michał Stasiakiewicz emphasizes the role of a creative process in developing competences to act in human beings (2004).Creative action constitutes a separate communication channel (J. Kuster, 2007), which enables a disabled person to express emotions and states of mind.

Improvisation has been successfully used as a drama therapy technique. (K. Johnstone, 1989; A. Frost, R. Yarrow, 1990; A. Cattanach, 1992; S. Bailey, 1993; H. Cohen, 1995; V. Spolin, 1999 ). Following the DTM, it has been applied to preparing a performance inspired by Bruno Ferrero's stories (1997). By improvising, one agrees to interact with what is already known and understood, what is internalized, what refers to the clearly seen similarity between individual potential and new proposals or ideas. Then, there is an increased role of feedback in the form of reactions and engagement of others. There is also a greater chance to experimentally create a new experience and to gain knowledge from different sources.

\section{Research Methodology}

The aim of the research was to verify the hypothesis that the awareness of the role of the body in interpersonal relations changes in teenagers, aged 15-19, with moderate intellectual disability by participation in drama therapy workshops involving improvisation.

As regards acts of communication in improvised situations, it was expected that the actors will gain a better understanding and mastery of signals sent by their personal physicality (emotions) and experience various human behaviours and reactions (attitudes and mindsets).

A pedagogical experiment with a pre-test and post-test was used. The experiment followed a pilot study aimed to determine whether the instrument used is appropriate for individuals with a moderate intellectual disability. The Progress Assessment Charts (P-A-C), developed by. H. C. Gunzburg (1973 and 1974) to measure the social competence, are not intended to assess nonverbal communication as such (T.Witkowski, 1996). There are no other tests or scales to test non-verbal behaviours in interpersonal communication that are standardized on Polish population of moderately intellectually disabled adolescents (A. Frydrychowicz, E. Koźniewska., M. Sobolewska, E, Zwierzyńska, 2004),therefore the instrument used for the initial analysis was a test construed by the author. The test, entitled 
"Body in Action," consists of 16 questions that examine the level of self-evaluation of non-verbal behaviours in specific relations with other people. These include the receiving and sending of nonverbal messages that are transmitted para-linguistically through gestures, facial expression, posture, appearance, physical distance, etc. In developing the test, the scale of communicative activity (SCA), designed by Z. Nęcki (2000), and, to some extent, a Likert scale ( R.Likert, 1932; McLeod, SA 2008) were used.

Before the final version of the questions was accepted, the subjects' understanding of the essence and context of the questions was checked. In order to assess the level of understanding and to adjust the questions to the capacity of disabled adolescents, four competent judges were appointed.

There were five possible responses to each question: I strongly agree, I agree, I disagree, I strongly disagree, difficult to say. The maximum number of points that the subjects might score was 64 . The more points the subject scored, the better the person's self-awareness was of the role of the body in interpersonal relationships.

The therapeutic sessions followed the drama therapy model (DTM) ( Stefańska, 2012), which assumes the focus on understanding the situational context of the role and on reinforcing the repertoire of non-verbal behaviours by developing expressiveness of the body, gestures and facial expressions (W. Sikorski, 2013, pp. 16-30).

Drama therapy sessions for adolescents with moderate intellectual disability were conducted by the author in the period from September, 2013 to the end of February, 2014. There were 20 two-hour sessions conducted in Junior High School No 11 in Kalisz and 20 two-hour sessions in Janusz Korczak School in Ostrów Wielkopolski.

\section{Result Analysis}

The study comprised 40 research participants, aged 15-19, with a moderate intellectual disability, all of whom attended a junior high school. The table below presents the distribution of the subjects by sex.

The subjects were divided into two groups: an experimental one ( 6 girls +4 boys, Ostrów Wielkopolski and 5 girls +5 boys , Kalisz $)(n=20 ; 50 \%)$, in which drama therapy was applied and a control one ( 5 girls +5 boys, Ostrów Wielkopolski and 4 girls +6 boys, Kalisz $(n=20 ; 50 \%)$, in which no therapy was used.

The aim of the study was to examine whether therapy positively affected the results on the BODY scale. A two-factor analysis of variance in a mixed model 
was conducted. The between-group factor was the use of drama therapy and the within-group factor was another measurement on the BODY scale. The table below presents the results obtained in the study.

Table 1. Distribution of the subjects by sex

\begin{tabular}{lcc}
\hline \multicolumn{1}{c}{ Sex } & Number & Percentage \\
\hline Female & 20 & 50 \\
\hline Male & 20 & 50 \\
\hline
\end{tabular}

Table 2. Level on the BODY scale by use of drama therapy and time of measurement

\begin{tabular}{llcc}
\hline $\begin{array}{l}\text { Time } \\
\text { of measurement }\end{array}$ & $\begin{array}{l}\text { Drama } \\
\text { therapy }\end{array}$ & Mean & $\begin{array}{c}\text { Standard } \\
\text { deviation }\end{array}$ \\
\hline Start of study & No & 29.15 & 6.06 \\
\cline { 2 - 4 } & Yes & 28.40 & 5.08 \\
\cline { 2 - 4 } & Overall & 28.78 & 5.54 \\
\hline \multirow{2}{*}{ End of study } & No & 28.90 & 5.82 \\
\cline { 2 - 4 } & Yes & 45.90 & 4.84 \\
\cline { 2 - 4 } & Overall & 37.40 & 10.10 \\
\hline
\end{tabular}

The variance analysis showed a statistically significant main effect of the time of measurement: $\mathrm{F}(1.38)=126.66 ; \mathrm{p}<0.001$. This indicates that irrespective of the group, in the final measurement the higher level on the BODY scale was achieved as compared with the initial measurement.

The variance analysis also showed a statistically significant effect of interaction between the time of measurement and the group examined: $F(1.38)=134.11$; $\mathrm{p}<0.001$. This means that the differences between initial and final measurements change depending on the group examined.

The analysis of simple effects distributed by the group examined showed that in the control group there were no statistically significant differences in the level on the BODY scale between the initial and final measurements: $p=0.819$, whereas in the experimental group a higher level was observed on the BODY scale after drama therapy: $\mathrm{p}<0.001$.

The analysis of simple effects distributed by the time of measurement showed that in the initial measurement there were no statistically significant differences between the control group and the experimental one in terms of the level on the 
BODY scale: $p=0.674$, whereas in the final measurement the subjects who had undergone drama therapy achieved a higher level than those from the control group: $\mathrm{p}<0.0001$.

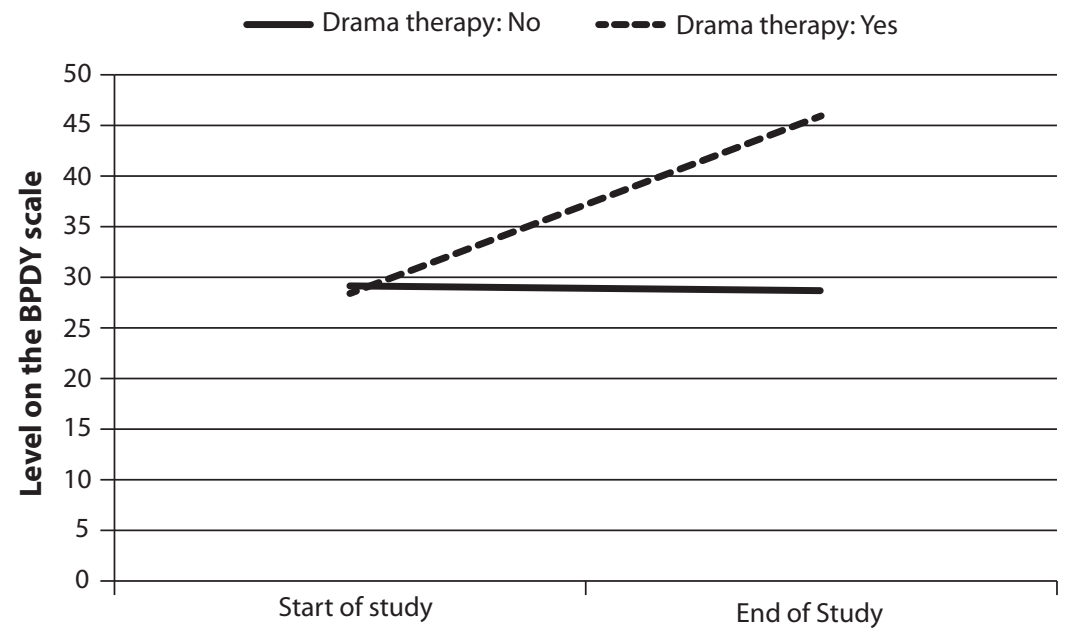

\section{Conclusions}

It results from the study that drama therapy utilizing improvisation significantly increases the level of self-awareness of adolescents with a moderate intellectual disability as regards the role of the body in interpersonal relationships. The individuals who exhibit higher levels of understanding nonverbal behaviours - both their own and others' - in interpersonal communication, clearly see their impact on the exchange of feelings and emotions. In particular, this awareness affects the use of gestures and understanding their connection with the content of the message as well as the proper use of such para-linguistic factors as facial expression, body posture, appearance and physical distance. It can be assumed that drama therapy sessions following the DTM and based on improvisation facilitate the recognition of the meaning of emotions revealed in the creative process. This is likely to increase the purposefulness of communicative expression in persons with intellectual disabilities.

The study shows that there is a correlation between participation in drama therapy based on improvisation and the level of the participants' self-awareness of the role of the body in interpersonal relationships. However, the author is aware that, at this stage, the conclusions should not be extended so as to apply to the 
whole age-group of the intellectually disabled. The results may be used to indicate an area in drama therapy that is worth further exploration.

In pure theatre art, the task of the body is to intentionally - more or less expressively - mediate between the character played and the spectator, so that the latter might read out or even feel the meaning of the character's each movement. Thus, the channel of non-verbal communication mutually complements that of verbal communication. In the drama therapy of the intellectually disabled, the body is a basic theatrical means of expression. Usually, in the process of building a character, a disabled person needs external stimuli, including those that are inaccessible to them in everyday life. Few homogenous interpersonal relationships, clear disproportion in communication abilities or excessive care and hasty disbelief in people's potential, which prevail in their environment, prevent them from developing and mastering their expressiveness and relationship communication. Therefore, in drama therapy, acting tasks are aimed to directly support inner development of the "acting" person. In this process of expressing oneself by means of body movement, it often happens that the limits that so far seemed insurmountable are overcome.

In drama therapy, the process of role building - if it is adjusted to the actor means entering the dramatic reality. Participants who lack experience in sensing their bodies in interpersonal relationships and exhibit a low level of the awareness of non-verbal behaviours are thus given an opportunity to feel the power and variety of uncommon stimuli. Improvisation is aided, above all, by the actors observing one another. Stephen Books states that by observing the work of others, individuals will be able to see how they cope with problems that they themselves have just encountered or will encounter in a moment (2007, p. 19). An attempt to express by individual movement, in one's own rhythm, what you already know and understand about the character you play, requires personal engagement of the participant. It is even more difficult when physicality on stage is in opposition to mental and emotional presence. Motor behaviours, their fugacity and unpredictability, reflect a specific, individual emotional expression. Future usefulness of body work in theatrical improvisations consists in referring to onstage experiences in everyday activities (J.M Cagigal, 1995, p.72).

Drama workshops give the intellectually disabled an opportunity to break the barriers of controlled or routine behaviours and too obvious reactions of the body. Drama workshops involving body work may open new areas of activity for the disabled, free them from apathy or isolation and release and activate the potential of their imagination. This in turn makes it possible to satisfy such psychic needs as acceptance, pleasure, or contact with others. 


\section{References}

Arystoteles (2006). Polityka. L.M. Piotrowicz, M. Szymański (oprac.). Warszawa: PWN.

Bailey, S.D. ( 1993). Wings To Fly: Bringing Theatre Arts To Students With Special Needs. Bethesda, MD: Woodbine House.

Cagigal, J.M.( 1995). Kształcenie człowieka cielesnego, w: P. Lengrand (red.). Obszary permanentnej samo-edukacji. Warszawa: WSSP.

Cattanach, A. (1992). Drama for People with Special Needs, New York: Drama Book Publishers.

Cohen, H. (1995). Dramatically able: Making drama accessible to participants with disabilities. Ann Arbor, MI: Wild Swan Theatre.

Duda, A (2006). Teatr realności O iluzji i realności w teatrze współczesnym. Wydawnictwo: Słowo/Obraz Terytoria

Ferrero, B. (1997). Historie piękne : dla szkoły i katechezy. Warszawa: Wydawnictwo Salezjańskie

Fromm, E ( 2005). O sztuce istnienia, Warszawa: PWN.

Frost, A., Yarrow, R. (1990). Improvisation in Drama, Macmillan London: Macmillan.

Frydrychowicz, A., Koźniewska, E., Sobolewska, M., Zwierzyńska, E. (2004). Testy psychologiczne i pedagogiczne w poradnictwie. Przewodnik metodyczny, wyd.

drugie rozszerzone. Warszawa, Wydaw. Centrum Metodyczne Pomocy PsychologicznoPedagogicznej.

Gardner, H. (1993). Multiple Intelligences: The Theory in Practice. New York: Basic.

Huston, H. (1996). Flavors of physicality, Journal of Dramatic Theory and Criticism Vol. XI, No.1:Fall

Jennings, S.E. ( 1995). Playing for Real. International Play Journal, 3.,132-141.

Johnstone, K. (1989). Impro: Improvisation and the Theatre, New York: Routledge.

Johnson, D. (1985). Expressive group therapy with the elderly: a drama therapy approach. International Journal of Group Psychotherapy, 1, 109-127.

Krasoń, K. (2013). Cielesność aktu tworzenia w teatrze ruchu. Kraków: UNIVESITAS.

Knill, P, Barba, H, Fuchs, M.(1995). Minstrels of the soul: Intermodal expressive therapy. Toronto:Palmerson Press.

Kuster, J. (2007). Communicating through Art., ASHA Leader, t.12 nr 10

Laban, R., Laban's Principles of Dance and Movement Notation. $2^{\text {nd }}$ edition edited and annotated by R. Lange. London: MacDonald and Evans. (First published 1956)

Jejte Lewkowicz, I., Piasecka, A. ( 2006). Terapia i teatr, Łódź: Tercja.

Likert, R. (1932). A Technique for the Measurement of Attitudes. Archives of Psychology 140: $1-55$.

Lowen, A. (2005). The Voice of the Body: The Role of the Body in Psychotherapy: Bioenergetics Press

McLeod, S.A. (2008). Skala Likerta. Retrieved 02.04.2015 from http://www.simplypsychology.org/likert-scale.htm

Malchiodi, C.A. ( 2014). Arteterapia. Gdańsk: UNIVERSALIS.

Merleau-Ponty, M. ( 2002). Phenomenology of Perception, London: Psychology Press. 
Nęcki, Z. (2000). Komunikacja międzyludzka. Kraków, Wydaw. Antykwa.

Nowakowska M. (2006). Dramaterapia i gra. Czasopismo Psychologiczne, Tom 12, Nr 1, 2006, 7-24,

Podgórska-Jachnik, D. ( 2011). Refleksje o teatrze osób niepełnosprawnych w kontekście ich edukacji, samorealizacji i terapii w: Stymulowanie potencjału twórczego osób z róznymi potrzebami edukacyjnymi, red. E. Lubinska-Kościólek i K. Plutecka, Kraków: Impuls.

Rayska, A. (2014). "Poruszenie". Praca metoda psychoterapii tańcem i ruchem z młodzieża w szkole integracyjnej, w: Z.Pędzich (red.) Psychoterapia tańcem i ruchem, Sopot: GWP .

Rakusin, A. (1990). A dance/movement therapy model incorporating movement education concepts for emotionally disturbed children, The Arts in Psychotherapy, Nr. 17., 1990. 17 (2), 55-67.

Spolin, V. (1999). Improvisation for the Theatre, Illinois :Northwestern University Press.

Rogers , C. ( 2002). O stawaniu się osobą, Poznań :Dom Wydawniczy Rebis.

Sikorski, W. (2013) Komunikacja Terapeutyczna. Relacja pozasłowna. Kraków: Impuls.

Stasiakiewicz, M (2004). Proces twórczy jako zdobywanie kompetencji działania [in:] Twórczość $w$ teorii i praktyce S. Popek (ed.), Lublin .

Stefańska, A. (2012). Teatroterapia jako metoda kształtowania poczucia godności u osób niepetnosprawnych, Poznań- Kalisz: Biblioteka Arteterapeuty.

Steiner, R. (2003). Wiedza dawnych misteriów . Gdynia:. Genesis.

Stern, D.N. (2004). The present moment in psychotherapy and everyday life. New York: Norton \& Company.

Witkowski, T. (1996). Podręcznik do Inwentarza pac -1 h.c. Gunzburga do oceny postępu w rozwoju; społecznym osób z upośledzeniem umysłowym. Lublin. 